\title{
Weeding Frequency to Increase Productivity of Sorghum in Gumara -Maksegnit Watershed
}

\author{
Yimer Abeje, Tsedalu Jemberu*, Tesfay Jorgi
}

Gondar Agricultural Research Center, ETHIOPIA

${ }^{*}$ Corresponding Contact:

Email: tsedalu2009@gmail.com

Manuscript Received: 04 March 2020 - Revised: 21 April 2020 - Accepted: 28 April 2020

\begin{abstract}
In Amhara region, Ethiopia, sorghum production took 655,671 hectare of land, of which North Gondar zone accounts one third of it, 204, 686 ha. But its productivity is low, around 1.9 tons per hectare. Sorghum production has so many constraints, insect pest, disease and weed infestation are the most known among of them. Farmers in the North western Ethiopia, Gumara-maksegnit watershed have no weeding habit of their sorghum at the right time and frequency, because they believe that weed free crops at the early stage of the crop will be infested with stalk borer damage and after at the beginning of September they start to weed their land and used the weed as a feed for their animal. Therefore the objective of this study was to determine weeding frequency of sorghum in Gumara-maksegnit watershed, North Western Ethiopia in order to increase its productivity. The experiment was conduct in the Gumara- maksegnit watershed for two cropping seasons (2014-2015) in the main season at three sites. The experimental design was arranged in randomized complete block design with three replications. Treatments like weed free, unweeded, and farmers practice treatments, hand weeding once, two times hand weeding, three times hand weeding and Shelshalo were studied. According to the combined analysis of variance of the two-year data showed that weed free treatments gave the highest yield $(3314 \mathrm{~kg} / \mathrm{ha})$ followed by two times and three times hand weeding. However, here was no significance difference between weed free and two times hand weeding. Therefore, two times hand weeding is recommended for Gondar Zuria and similar agro ecological areas.
\end{abstract}

Keywords: Sorghum, weed, productivity, North Western Ethiopia

This article is is licensed under a Creative Commons Attribution-NonCommercial 4.0 International License.

Attribution-NonCommercial (CC BY-NC) license lets others remix, tweak, and build upon work non-commercially, and

although the new works must also acknowledge \& be non-commercial.

\section{INTRODUCTION}

Cereal crop production in the country accounts 80.78 percent of the total grain production. Of which Sorghum production took up to $14.58 \%$ (1.83 million ha) from the total grain production. In Amhara region, Ethiopia, sorghum produced 655,671ha of land, North Gondar zone, took 204, 686 ha (CSA, 2007). But its productivity is low, around 1.9 tons per hectare. 
Sorghum production has so many constraints, insect pest, disease and weed infestation are the most known among of them. Farmers in Ethiopia commonly lose up to $40 \%$ of their crops due to weed infestations (Kebede Desta, 2000). Although Maize (Zea mays) is susceptible to competition from weeds, with commonly reported yield losses greater than 30\% (Chikoy \& Ekeleme, 2003; Hassan et al., 2010). Because it is not normally planted in rows, weeding is a time-consuming task, taking up to $140 \mathrm{hr} / \mathrm{ha}$. Most farmers in Ethiopia as well as in Amhara Region do not weed their fields at the right time because of labor bottlenecks. Weeds are therefore one of the most important crop production constraints in the country and the region.

Weeds growing among crop plants adversely affect yield and quality of the harvest and increase production costs, resulting in high economic losses. Some species of weed plants might be a serious threat to crop plants diversity, sharing nutrients, moisture, sun light and space (Ozturk et al, 2012). Meanwhile, to consolidate the expansion of the cultivated area with sweet sorghum, and to achieve satisfactory yield potential, it is necessary to properly conduct the treatments in the crop. The integrated weed management stands out as one of the main bottlenecks in the production system, because the weed control in inappropriate time may adversely affect the production cost and/or result in qualitative and quantitative losses in crop yield (Ciuberkis et al., 2007).

The most troublesome weeds in sorghum include Striga (Striga hermonthica), Nut-grass (Cyperus rotundus), and other common narrow and broad leaved weeds. Farmers in the North western Ethiopia, Gumara-maksegnit watershed have no a weeding habit of their sorghum at the right time and frequency, because they believe that weed free crops at the early stage of the crop will got stalk borer damage (farmers suggestion during interview). And after at the beginning of September they start to weed their land and used the weed as a feed for their animal (Personal observation). Identifying factors that could affect crop competitive ability independently or synergistically with known factors over a wide range of situations is therefore important to enhance crop competitive ability (Tomar et al., 2003).Therefore the objective of this study was to determining better weeding frequency of sorghum in Gumara-Maksegnit watershed, North western Amhara.

\section{MATERIALS AND METHOdS}

\section{Site Description}

The experiment was conduct in the Gumara- maksegnit watershed, North Western Ethiopia, for two cropping seasons (2014-2015) at three sites. Annual rainfall in the year 2014 and 2015 was 1418 and $1108 \mathrm{~mm}$ respectively (Figure 1). The mean maximum temperature of the area is about $28.5{ }^{\circ} \mathrm{C}$ and while the mean minimum temperature is about $13.3^{\circ} \mathrm{C}$.

The soil status of the experimental area showed that the $\mathrm{PH}$ value of both sites laied on neutral soil conditions. The available Phosphrus content of the experimental site-1 indicated that, it has very low Available soil phosphorus content when compared to site 2, which have relatively high soil phosphorus. But both experimental sites have low available phosphorus content when compared to the critical P content for crop growth which is characterized as low $<23$, medium 23-56 and high $>56$ ppm (Tandon, 2004). 


\section{Annual rainfall (mm)}

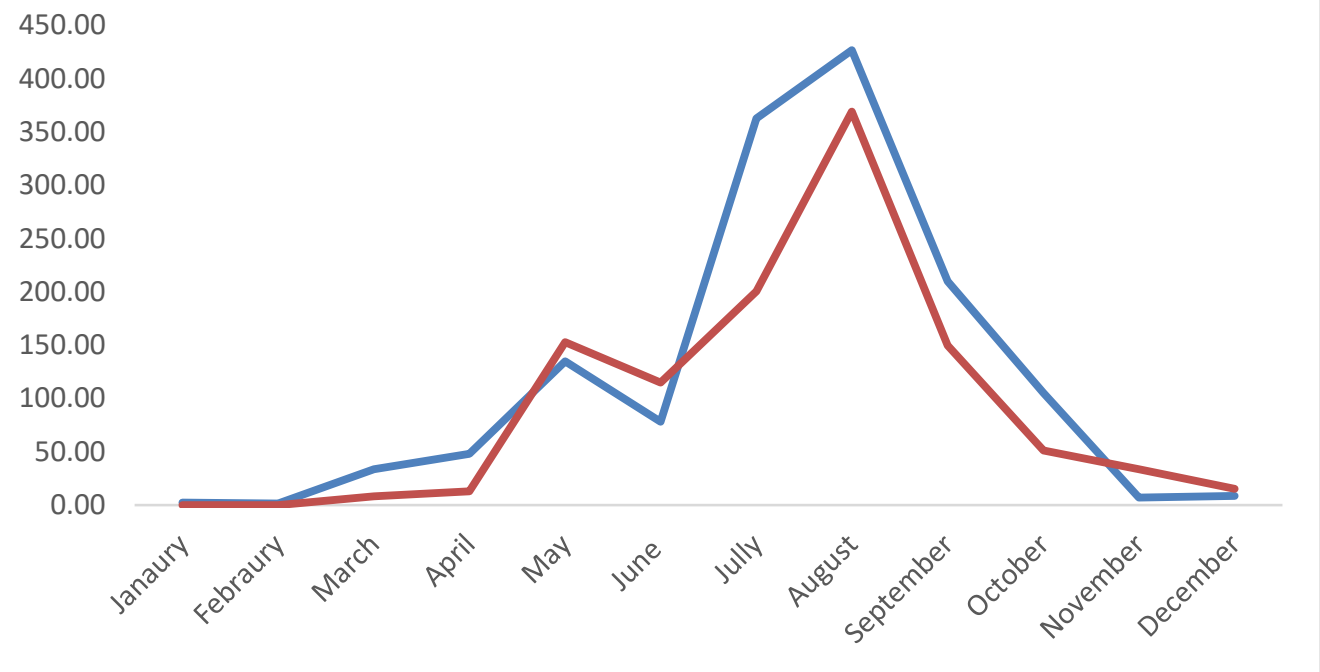

Figure 1: Annual rainfall distribution

\section{Experimental Design and Analysis}

The experimental design was arranged in randomized complete block design with three replications. The plot size was $4.5 \mathrm{~m} \times 5 \mathrm{~m}\left(22.5 \mathrm{~m}^{2}\right)$ with six rows, Ridge and furrow planting method was used on black soil. Local sorghum variety was used at a seed rate of $10 \mathrm{~kg} / \mathrm{ha}$ and planted in rows. The spacing between replications, plots, rows and plants was $1.5 \mathrm{~m}, 1 \mathrm{~m}, 75 \mathrm{~cm}$ and $15 \mathrm{~cm}$, respectively. The planting date of the experiment was on the second week of June for both years. Application of urea was applied at a rate of $41 \mathrm{~kg}$ $\mathrm{N} /$ ha in two splits (1/2 at planting and the rest was applied at knee height stage) whereas, $46 \mathrm{~kg} \mathrm{P}_{2} \mathrm{O}_{5} / \mathrm{ha}$ at was applied at planting.

\section{Treatments of the experiment}

1. HW1 -Hand weeding once (25 days after sorghum crop emergence/DAE/)

2. HW2-Two times hand weeding (25 and 55 days after sorghum crop emergence/DAE/)

3. HW3- Three times hand weeding $(25,55$ and 90 days after sorghum crop emergence/DAE/)

4. HW4- Farmers practice (weeding once at 80 days after sorghum crop emergence/DAE/)

5. HW5- Weed free plot

6. HW6- Control (Un weeded plot)

7. Shelshalo (Interrow cultivation with hand or animal drawn implements)

Statistical analysis: analysis of variance (ANOVA) was carried out to determine the presence of significant difference among the treatments using SAS 9.2 software mean separation was done using least significant difference. 


\section{RESULT AND Discussion}

The experiment was conducted on the vertisol of gumara maksegnit watershed, North gondar zone, ethiopia. The result revealed that, there were significance difference on heading days, plant height, thousand seed weight, grain yield and fresh biomass in 2014 . Farmers practice and unweeded treatment took longest days to heading which was 104 and 102 days respectively. It is probably because of the fact that, there is high competetion between sorghum crop and weeds for nuitrent especially and haveing slow growth. In this expeiment the highest grain yield was recorded on two times hand weeding $(2916 \mathrm{~kg} / \mathrm{ha})$ and weed free treatments $(2666 \mathrm{~kg} / \mathrm{ha})$.

Table 1: Soil properties of the experimental site

\begin{tabular}{|c|c|c|c|c|c|c|c|}
\hline No. & Site & $\mathrm{PH}\left(\mathrm{H}_{2} \mathrm{O}\right)$ & E.C & Available P/PPM & O.C\% & \multicolumn{2}{|c|}{ Texture (Hydrom.) } \\
\hline 1 & Tilahun-Site 1 & 7.1 & 0.03 & 7.68 & 071 & Clay loam & ---2014 \\
\hline 2 & Mande-Site 2 & 6.94 & 0.1 & 14.54 & 0.88 & Clay & ---2015 \\
\hline
\end{tabular}

Whereas the lowest grain yield were recorded on unweeded treatments, farmers practice and one times weeding which was 1778, 1836 and $2003 \mathrm{~kg} /$ ha respectively (Table 1). this reveald that, weeding in sorghum production at gondar zurria woreda ha significance effect on grain yield.

Table 2: List of weeds observed in the experimental area

\begin{tabular}{|c|l|l|l|l|}
\hline N0. & $\begin{array}{c}\text { Weed Type in } \\
\text { heavy clay soil } \\
\text { (Amharic) }\end{array}$ & $\begin{array}{c}\text { Weed Type in heavy } \\
\text { clay soil (Scientific } \\
\text { Name) }\end{array}$ & $\begin{array}{c}\text { Weed type in } \\
\text { light soil } \\
\text { (Amharic) }\end{array}$ & \multicolumn{1}{|c|}{$\begin{array}{c}\text { Weed type in } \\
\text { light soil (Scientific Name) }\end{array}$} \\
\hline 1 & Gicha & Cyperus rotundus L. & Lolia & Commelina benghalensis \\
\hline 2 & Enat kurit & Chenopodium murale & Gicha & Cyperus rotundus L. \\
\hline 3 & Chilika & Cynodon nlefuensis & Enat kurit & Chenopodium murale \\
\hline 4 & Yewusha milas & Scorpiurus muricatus & Mech & Guizotia scabra \\
\hline 5 & Nech abeba & Tagetes minuta & Akakma & Oxygonum sinuatum \\
\hline & & & Maget & Medicago polymorpha L. \\
\hline & & & Meskel ferche & Galinsoga parviflora \\
\hline & & & Nech abeba & Tagetes minuta \\
\hline
\end{tabular}

Almost all treatments gave the highest fresh biomass yield except farmers practice which gave the lowest biomass yield of sorghum, $8.04 \mathrm{t} / \mathrm{ha}$. The highest were recorded from weed free experimental plots and followed by three times hand weeding (Table 3 ).

Table 3: Mean Value of HD, MD, PH, TSW, Yield and Fresh Biomass of sites sorghum in G/Maksegnit watershed on 2014

\begin{tabular}{|l|l|l|l|l|l|l|}
\hline Treatment & HD & MD & PH & TSW & Yield kg/ha & Fresh biomass \\
\hline HW1 & $99.0 \mathrm{~b}-\mathrm{d}$ & 184.0 & $172.8 \mathrm{~b}$ & $35.2 \mathrm{ab}$ & $2003 \mathrm{~b}$ & $9.6 \mathrm{cde}$ \\
\hline HW2 & $96.0 \mathrm{~b}$ & 180.6 & $180.0 \mathrm{ab}$ & $35.5 \mathrm{a}$ & $2916 \mathrm{a}$ & $12.1 \mathrm{ab}$ \\
\hline HW3 & $98.0 \mathrm{~cd}$ & 185.6 & $176.6 \mathrm{~b}$ & $36.0 \mathrm{a}$ & $2663 \mathrm{ab}$ & $12.0 \mathrm{abc}$ \\
\hline FP & $104.0 \mathrm{a}$ & 185.3 & $175.0 \mathrm{ab}$ & $34.2 \mathrm{a}-\mathrm{c}$ & $1836 \mathrm{~b}$ & $9.2 \mathrm{de}$ \\
\hline WF & $97.6 \mathrm{~cd}$ & 182.0 & $183.2 \mathrm{a}$ & $33.2 \mathrm{bc}$ & $2666 \mathrm{ab}$ & $13.4 \mathrm{a}$ \\
\hline Control & $102.3 \mathrm{ab}$ & 183.3 & $171.6 \mathrm{~b}$ & $35.2 \mathrm{ab}$ & $1778 \mathrm{~b}$ & $8.3 \mathrm{e}$ \\
\hline Shelshalo & $101.3 \mathrm{a}-\mathrm{c}$ & 181.6 & $176.0 \mathrm{ab}$ & $32.3 \mathrm{c}$ & $2256 \mathrm{ab}$ & $11.0 \mathrm{bcd}$ \\
\hline LSD\% & 4.21 & 9.33 & 9.37 & 1.97 & 888 & 2.43 \\
\hline CV\% & 2.37 & 2.86 & 2.98 & 3.21 & 21.6 & 12.6 \\
\hline
\end{tabular}


The interaction effect of treatment with year, only sorghum thousand seed weight and fresh biomass showed significance difference (Table 3). However, the other important parameters like maturity days, plant height and grain yield of sorghum didn't show significance difference on the combined interaction effect of treatment with year.

In 2015 different weeding frequency has shown difference in thousand seed weight, grain yield and fresh biomass, however, maturity days and plant height didn't showed significance difference over the treatments. In the year 2015, the highest grain yield was observed on weed free treatments $(3638 \mathrm{~kg} / \mathrm{ha})$, followed by two times and three times hand weeding respectively. The lowest grain yield were observed on un weeded and farmer practice treatments which was $2433 \mathrm{~kg} / \mathrm{ha}$ and $2820 \mathrm{~kg} /$ ha respectively. In contrast, the highest biomass was recorded on un weeded treatment (Table 4).

Table 4: Mean Value of HD, MD, PH, TSW, yield and Fresh Biomass of sites sorghum in G/Maksegnit watershed on 2015

\begin{tabular}{|l|l|l|l|l|l|}
\hline Treatment & MD & PH & TSW & Yield kg/ha & Fresh biomass t/ha \\
\hline HW1 & 146.3 & 179.8 & $31.9 \mathrm{~b}$ & $2729 \mathrm{c}$ & $7.97 \mathrm{ab}$ \\
\hline HW2 & 145.3 & 188.2 & $32.5 \mathrm{ab}$ & $3254 \mathrm{ab}$ & $7.51 \mathrm{~b}$ \\
\hline HW3 & 147 & 185.3 & $32.0 \mathrm{~b}$ & $3250 \mathrm{ab}$ & $7.76 \mathrm{~b}$ \\
\hline FP & 146 & 183.4 & $34.3 \mathrm{a}$ & $2820 \mathrm{bc}$ & $7.42 \mathrm{~b}$ \\
\hline WF & 146.7 & 189.3 & $33.7 \mathrm{a}$ & $3638 \mathrm{a}$ & $7.23 \mathrm{~b}$ \\
\hline Control & 145.7 & 182.2 & $32.9 \mathrm{ab}$ & $2433 \mathrm{c}$ & $9 \mathrm{a}$ \\
\hline Shelshalo & 146.2 & 178.8 & $32.1 \mathrm{~b}$ & $2812 \mathrm{bc}$ & $7.56 \mathrm{~b}$ \\
\hline LSD\% & 3.75 & 13.8 & 2.02 & 505 & 1.2 \\
\hline LS & ns & ns & ns & $* *$ & ns \\
\hline Trt* Site & ns & ns & ns & ns & ns \\
\hline CV\% & 2.16 & 6.3 & 5.2 & 14.2 & 13.1 \\
\hline
\end{tabular}

The two years combined analysis of variance showed that, thousand seed weight, grain yield and fresh biomass showed significance difference, whereas, maturity days and plant height didn't showed significance difference. The effect of weed in crop depends greatly on crop species, type and level of weed infestation and environmental conditions (Hussein et al., 2007).

Table 5: Combined Mean Value of HD, MD, PH, TSW, yield and Fresh Biomass of sites sorghum in G/Maksegnit watershed on 2014 and 2015

\begin{tabular}{|l|l|l|l|l|l|}
\hline Treatment & MD & PH & TSW & Yield kg/ha & Fresh biomass \\
\hline HW1 & 158.9 & $177.5 \mathrm{~b}$ & $33.0 \mathrm{ab}$ & $2487 \mathrm{c}$ & $8.5 \mathrm{ab}$ \\
\hline HW2 & 157.1 & $185.4 \mathrm{ab}$ & $33.6 \mathrm{ab}$ & $3141 \mathrm{a}$ & $9.06 \mathrm{ab}$ \\
\hline HW3 & 159.9 & $182.4 \mathrm{ab}$ & $33.3 \mathrm{ab}$ & $3054 \mathrm{ab}$ & $9.19 \mathrm{a}$ \\
\hline FP & 159.7 & $180.6 \mathrm{ab}$ & $34.3 \mathrm{a}$ & $2492 \mathrm{c}$ & $8.04 \mathrm{~b}$ \\
\hline WF & 158.4 & $187.3 \mathrm{a}$ & $33.6 \mathrm{ab}$ & $3314 \mathrm{a}$ & $9.3 \mathrm{a}$ \\
\hline Control & 158.2 & $178.6 \mathrm{ab}$ & $33.7 \mathrm{ab}$ & $2215 \mathrm{c}$ & $8.78 \mathrm{ab}$ \\
\hline Shelshalo & 158.0 & $177.8 \mathrm{~b}$ & $32.2 \mathrm{~b}$ & $2627 \mathrm{bc}$ & $8.71 \mathrm{ab}$ \\
\hline LSD \% & & 9.14 & 1.5 & 439 & 1.12 \\
\hline LS & ns & ns & ns & $* *$ & $* *$ \\
\hline Tr*y & ns & ns & $*$ & ns & $*$ \\
\hline CV\% & 2.36 & 8.2 & 5.2 & 17.6 & 14.9 \\
\hline
\end{tabular}


In the combined analysis the highest grain yield were recorded from weed free, two times hand weeding and three times hand weeding treatments, $3314 \mathrm{~kg} / \mathrm{ha}, 3141 \mathrm{~kg} / \mathrm{ha}$ and 3054 $\mathrm{kg} / \mathrm{ha}$ respectively. Whereas, the lowest yield was recorded from the un weeded experimental plots which was $2215 \mathrm{~kg} / \mathrm{ha}$, followed by farmers practice $(2492 \mathrm{~kg} / \mathrm{ha})$. Two times hand weeding has yield advantage of 649 and $822 \mathrm{~kg} /$ ha over farmers weeding practice and weed free experimental plots.

The economic analysis was carried out for weeding frequency sorghum crop at Gumara maksegnit watershed. The variable cost components such as seed, fertilizer, bags (sacks), land preparation, planting, harvesting and threshing have similar costs across treatments and locations, so were considered in the analysis. The difference in the total variable cost of production between the treatments, timing and hand weeding frequency, was attributable to the differences in costs of labour cost of weeding in the treatments and across the locations.

Table 6: Economic analysis

\begin{tabular}{|l|c|c|c|c|c|c|c|}
\hline Treatment & Control & Shelshalo & HW1 & HW2 & FP & HW3 & WF \\
\hline Mean GY (kg/ha) & 2215 & 2627 & 2487 & 3141 & 2492 & 3054 & 3314 \\
\hline Strover yield kg/ha & 6565 & 6083 & 6013 & 5919 & 5548 & 6136 & 5986 \\
\hline Adj. yield (kg/ha) & 1993.5 & 2364.3 & 2238.3 & 2826.9 & 2242.8 & 2748.6 & 2982.6 \\
\hline Adj. Stover yield(kg/ha) & 5908.5 & 5474.7 & 5411.7 & 5327.1 & 4993.2 & 5522.4 & 5387.4 \\
\hline Adj. Stover yield(shekim/ha) & 295.425 & 273.735 & 270.585 & 266.355 & 249.66 & 276.12 & 269.37 \\
\hline GFB (ETB/ha) & 21340.1 & 23393.48 & 22432.7 & 26447.2 & 21941.1 & 26143.2 & 27612.5 \\
\hline Labor cost (ETB/ha) & 0 & 991.67 & 1118.06 & 2287.96 & 2300.93 & 2443.52 & 2565.50 \\
\hline TCV (ETB/ha) & 0 & 991.67 & 1118.06 & 2287.96 & 2300.93 & 2443.52 & 2565.50 \\
\hline TFC & 1500 & 1500 & 1500 & 1500 & 1500 & 1500 & 1500 \\
\hline Total Cost & 1500 & 2491.667 & 2618.06 & 3787.96 & 3800.93 & 3943.52 & 4065.5 \\
\hline NB (ETB/ha) & 19840.1 & 20901.81 & 19814.7 & 22659.2 & 18140.2 & 22199.7 & 23547 \\
\hline Dominance analysis & & & $\mathrm{D}$ & & $\mathrm{D}$ & $\mathrm{D}$ & \\
\hline MC (ETB/ha) & & 991.67 & & 1296.3 & & & 277.54 \\
\hline MNB (ETB/ha) & & 1061.68 & & 1757.4 & & & 887.74 \\
\hline MRR (\%) & & 107.06 & & 135.57 & & & 319.86 \\
\hline
\end{tabular}

As shown on table below use of hand weeding at 20,35 and 50 days after emergency were found profitable timing and frequency for upland rice production at current market condition as well as sensitivity analysis (table 6). The figure obtained is greater than the generally accepted minimum rate of return i.e. $100 \%$. This implies that for one birr additional cost on the use of hand weeding at 20,35 and 50 days after emergency have a return of birr 23.30. Similarly the sensitivity analysis showed hand weeding at 20, 35 and 50 days after emergency were found profitable timing and frequency for upland rice production if there is an increase in factor cost.

\section{Conclusion and Recommendation}

Sorghum production in the region as well as in the study area is considered as vital especially for home consumption and Stover used as animal feed. However, different biotic and abiotic factors play major role on the reduction of sorghum productivity and weed is one of it in the study area. This experiment was conducted at Gumara maksegnit watershed with the objective of improving its productivity through utilization of appropriate weed management options. The results of the experiment showed that the 
grain yield of sorghum crop is highly affected by weed. There is a yield loss from $822 \mathrm{~kg} / \mathrm{ha}$ in the un weeded field. Hence, weeds are found now a serious threat in sorghum production in the area, but relatively little attention has so far been paid to research on weed management.

The combined results of the two year data showed that weed free treatments gave the highest yield ( $3314 \mathrm{~kg} / \mathrm{ha}$ ) followed by two times and three times hand weeding. The economic analysis gave that, weed free (Three times weeding) gave 319\% MRR followed by two times hand weeding (135\% MRR) In general there was no significance difference between weed free and two times hand weeding. Therefore, two times hand weeding is recommended for Gondar Zuria and similar areas.

\section{ACKNOWLEDGMENT}

The Author would like to thank International Center for Agricultural Research in the Dry Areas (ICARDA) for financial support.

\section{REFERENCE}

Central Statistic Agency, 2007

Chikoye, D.; Ekeleme, F. 2003. Cover crops for cogongrass management and effects on subsequent corn yield. Weed Sci., v. 51, n. 5, p. 792-797.

Ciuberkis, S.; Bernotas, S.; Raudonius, S.; Felix, J. 2007. Effect of weed emergence time and intervals of weed and crop competition on potato yield. Weed Technology, v.21, p.213-218.

Hassan G: Tanveer S; Ullah khan. N; Munir M. 2010. Integrating cultivars with reduced herbicides rates for weed management in maize. Pakistan J. Bot., v. 42, n. 3, p. 1923-1929.

Hussein, F. et al. 2007. Effect of nitrogen rates and weed control treatments on maize yield and associated weeds in sandy soils. Weed Technol., v. 21, n. 4, p. 1049-1053.

Kebede Desta. 2000. Weed control methods used in Ethiopia. In: Starkey, P. and Simalenga, T. (eds)., Animal power for weed control. Technical Centre for Agricultural and Rural Cooperation (CTA), Wageningen, The Netherlands.

Ozturk M, U Kebapci, S Gucel, E Cetin, E Altundag. 2012. Biodiversity and land degradation in the lower Euphrates sub region of Turkey. J Environ Biol 33(2): 311-323.

Tandon, H.L.S. 2004. Fertilizers in Indian Agriculture - from 20th to 21st century. FDCO, New Delhi, India. pp. 240.

Tomar, R.K., J.P. Singh, R.N. Garg, V.K. Gupta, R.N. Sahoo and R.P. Arora. 2003. Effect of weed management practices on weed growth and yield of wheat in rice based cropping system under varying levels of tillaye. Ann. Plant Protec. Sci., v. 11, n. 1, p. 123-128. 


\section{How to cite this article}

Abeje, Y., Jemberu, T., \& Jorgi, T. (2020). Weeding Frequency to Increase Productivity of Sorghum in Gumara -Maksegnit Watershed. ABC Journal of Advanced Research, 9(1), 31-38. https://doi.org/10.18034/abcjar.v9i1.502 